\title{
Kadar seng dan kadar malondialdehyde pada penderita multi drug resistant tuberculosis dan tuberkulosis sensitif
}

\author{
Suparno $^{1,4^{*}}$, Suhartono ${ }^{2}$, Muchlis Achsan Udji Sofro ${ }^{3}$, Mohammad Sulchan $^{4}$, Kusmiyati $^{5}$
}

\section{ABSTRACT}

Background: Zinc is the main constituent element of Superoxide Dismutase (SOD) which acts to protect cells from inflammation and the toxic effects of Reactive Oxygen Species (ROS). High ROS production induces fat peroxidation, and forms malondialdehyde (MDA) which causes oxidative stress.

Objectives: This study aimed to analyze the difference of zinc and malondialdehyde levels among Multi Drug Resistant Tuberculosis and sensitive Tuberculosis.

Methods: Crossectional study with 55 subjects consisted of 32 MDR-TB subjects and 23 subjects TB sensitive. Selection of subjects using consecutive sampling. Zinc and MDA serum was obtained from venous blood. Zinc and MDA concentration were assessed by quantitative colometric and Thiobarbituric Acid Reactive Substances (TBARS) respectively. Data were analized statistic by independent t-test and Mann Whitney test.

Results: Zinc level of MDR-TB and TB sensitive were 74.85 (64 - 97) $\mu \mathrm{g} / \mathrm{dl}$ and 73.03 (63 - 97) $\mu \mathrm{g} / \mathrm{dl}$ respectively, while MDA of MDR-TB and sensitive TB were $2.262 \pm 1.055 \mathrm{nmol} / \mathrm{mL}$ and $2.66 \pm 0.992 \mathrm{nmol} / \mathrm{mL}$. There was no significantly different in zinc level between MDR-TB and sensitive TB $(p=1.000)$. Furthermore, there was not significantly different of MDA level between $M D R-T B$ and sensitive Tuberculosis $(p=0,147)$.

Conclusion: There are no differences in zinc and MDA levels in patient between MDR-TB and sensitive TB.

Keywords: $M D A, M D R-T B, T B$-sensitif, and zinc

\begin{abstract}
ABSTRAK
Latar Belakang : Seng adalah penyusun utama Superoxide Dismutase (SOD) yang berperan melindungi sel dari inflamasi dan efek toksik Reaktive Oxygen Species (ROS). Produksi ROS yang tinggi menginduksi peroksidasi lemak, dan membentuk malondialdehyde (MDA) yang menyebabkan stress oksidatif

Tujuan : Menganalisis perbedaan kadar seng dan kadar malondialdehyde pada penderita MDR-TB dan TB sensitif.

Metode : Penelitian crossectional dengan jumlah subjek sebanyak 55 pasien yang terdiri dari 32 subjek MDR-TB dan 23 subjek $T B$ sensitif. Pemilihan subjek menggunakan consecutive sampling. Serum seng dan MDA diperoleh dari darah vena. Pemeriksaan kadar seng dan kadar MDA menggunakan spesimen darah. Pemeriksaan kadar seng dan MDA menggunakan metode Quantitative Colorimetric dan Thiobarbituric Acid Reactive Substances (TBARS). Data dianalisis menggunakan uji statistik independent t-test dan Mann Whitney test.

Hasil : Kadar seng pada MDR-TB dan TB sensitif masing-masing 74,85 (64 - $97 \mu \mathrm{g} / \mathrm{dl}$ ), dan 73,03 (63-97 $\mu \mathrm{g} / \mathrm{dl})$, sementara kadar MDA MDR-TB and TB sensitif 2.262 $\pm 1.055 \mathrm{nmol} / \mathrm{mL}$ dan $2.66 \pm 0.992 \mathrm{nmol} / \mathrm{ml}$. Tidak terdapat perbedaan kadar seng antara MDR-TB dan TB sensitif $(p=1,000)$. Selain itu, tidak ada perbedaan kadar MDA antara MDR-TB dan TB sensitif $(p=0,147)$.
\end{abstract}

Simpulan : Tidak ada perbedaan kadar seng dan kadar MDA pada MDR-TB dan TB sensitif.

Kata Kunci : MDA, MDR-TB, TB-sensitif, dan seng

\section{PENDAHULUAN}

Tuberkulosis (TB) adalah penyakit menular yang disebabkan oleh infeksi bakteri Mycobacterium tuberculosis (M.tb). Bakteri M.tb merupakan bakteri patogen pada paru, namun dapat menyebabkan penyakit di hampir seluruh bagian tubuh. ${ }^{1-4}$ Tuberkulosis menjadi penyebab utama morbiditas dan mortalitas di negara- negara yang berpendapatan rendah dan berpenghasilan menengah. ${ }^{5}$ Penderita tuberkulosis paru di dunia tahun 2014 sebanyak $\pm 9,6$ juta kasus dan tahun 2015 sebanyak $\pm 10,4$ juta kasus. ${ }^{6,7}$ Penderita tuberkulosis paru di Indonesia pada tahun 2015 sebanyak 330.910 kasus dan meningkat pada tahun 2016 menjadi 351.893 kasus. Kasus TB paru di Indonesia didominasi oleh provinsi dengan jumlah penduduk besar yaitu Provinsi Jawa

\footnotetext{
${ }^{1}$ Dinas Kesehatan Kabupaten Wakatobi, Provinsi Sulawesi Tenggara. Jl. La Ode Ali No.8 Padaraya Makmur, Kec. Wangi-Wangi 93791

${ }^{2}$ Departemen Keseharan Masyarakat, Fakultas Kesehatan Masyarakat, Universitas Diponegoro. Jl. Prof. Sudarto SH, Tembalang, Semarang, Jawa Tengah 50275

${ }^{3}$ Bagian Penyakit Dalam, Fakultas Kedokteran Universitas Diponegoro / Rumah Sakit Dr. Kariadi. Jl. Dr. Sutomo No.16, Kota Semarang, 50244

${ }^{4}$ Departemen Ilmu Gizi, Fakultas Kedokteran, Universitas Diponegoro. Jl. Prof. Sudarto SH, Tembalang, Semarang, Jawa Tengah 50275, Indonesia. Telepon/ Faximile (024) 8453708

${ }^{5}$ Bagian Biokimia, Fakultas Kedokteran Universitas Diponegoro. Jl. Dr. Sutomo No.16, Kota Semarang, 50244

* Korespondensi : E-mail: suparno.gz@ gmail.com, Telp/HP. 082143033304
} 
Barat 70.715 kasus, Jawa Timur 48.808 dan Jawa Tengah 35.743 kasus. ${ }^{8} 9$ Upaya pencegahan dan penanggulangan tuberkulosis secara keseluruhan terus dilakukan. Munculnya Multi Drug Resistant Tuberculosis (MDR-TB) menjadi beban ganda dalam penanggulangan tuberkulosis. Multi Drug Resistant Tuberculosis adalah tuberkulosis yang resisten terhadap dua obat anti tuberkulosis yaitu rifampisin dan isoniazid. $^{10}$ Jumlah penderita $M D R-T B$ di dunia meningkat dari tahun 2014 sampai 2015 yaitu dari 480.000 kasus menjadi 580.000 kasus, sedangkan di Indonesia juga terjadi peningkatan dari 9.399 kasus pada tahun 2014 menjadi 15.380 kasus pada tahun 2015.7,11

Penyakit menular kronis ditandai dengan peningkatan respon kekebalan tubuh yaitu proses yang menyebabkan kerusakan sel. Salah satu respon awal kekebalan bawaan inang adalah produksi Reaktive Oxygen Species (ROS) sebagai reaksi terhadap mikroba patogen. ${ }^{12-16}$ Ketidakseimbangan antara produksi ROS dan kapasitas antioksidan menyebabkan keadaan stres oksidatif. Produksi ROS yang berlebihan menyebabkan reaksi berantai dan menginduksi peroksidasi lipid terutama mempengaruhi fosfolipid yang mengandung polyunsaturated fatty acid (PUFA) sehingga menghasilkan malondialdehyde (MDA). ${ }^{16,17}$ Kadar MDA plasma yang tinggi sebagai penanda stres oksidatif semakin tinggi ${ }^{17,18}$ Stres oksidatif menyebabkan gangguan sinyal transduksi terhadap mycobacterium tuberculosis, gangguan sintesis DNA dan RNA. ${ }^{19}$ Mutasi pada gen katG dan inhA serta rpoB menyebabkan terjadinya $M D R-T B$. Mutasi gen tersebut menyebabkab resitensi terhadap obat Isoniazid dan Rifampisin. ${ }^{20}$ Penelitian sebelumnya oleh Kulkrani, et al., menunjukkan bahwa tingkat MDA dalam serum pasien tuberkulosis paru lebih tinggi dibandingkan dengan kontrol sehat. ${ }^{18,21}$

Aktivitas produksi ROS dipengaruhi oleh kondisi radikal bebas. Sel berupaya melindungi diri dari bahaya radikal bebas dengan sistem antioksidan endogen berupa enzim antioksidan seperti superoksida dismutase (SOD), katalase, glutation peroksidase, glutation reduktase dan seruloplasmin. Salah satu penyusun antioksidan endogen adalah mineral seng. Apabila sistem antioksidan endogen tidak mencukupi, dibutuhkan antioksidan dari luar. ${ }^{22,23}$ Antioksidan enzimatis mendetoksifikasi ROS dan RNS (Reactive Nitrogen Species) serta meminimalisir kerusakan pada biomolekul. ${ }^{16,24}$ Mekanisme seng dalam menurunkan ROS yaitu dengan penghambat oksidasi Nikotinamida Adenin Dinukleotida Phospat (NADPH), dan berfungsi untuk pembentukan SOD yaitu enzim yang mengandung seng dan tembaga yang dapat menurunkan stres oksidatif dan menginduksi metallothionein (MT) yang sangat efektif dalam menurunkan beban radikal hidroksil $(-\mathrm{OH}){ }^{22,25,26}$ Penelitian sebelumnya dilakukan oleh Bahi et.al., menunjukkan bahwa kadar serum seng ditemukan lebih rendah pada pasien MDR-TB dibandingkan dengan kontrol sehat. ${ }^{1}$

Penderita MDR-TB dan TB sensitif yang terdiagnosis $\mathrm{TB}$ aktif mempunyai kadar seng sebagai antioksidan ditemukan lebih rendah, sedangkan kadar MDA sebagai penanda stres oksidatif ditemukan dengan kadar yang tinggi. Terjadinya mutasi gen karena gangguan sistesis DNA dan RNA yang diakibatkan oleh stres oksidatif menyebabkan kuman TB menjadi resisten. ${ }^{27}$ Penelitian ini bertujuan untuk mengetahui apakah terdapat perbedaan kadar seng dan MDA pada penderita MDR-TB dan TB sensitif.

\section{BAHAN DAN METODE}

Desain penelitian adalah observasional dengan pendekatan cross sectional study. Subjek diambil menggunakan teknik consecutive sampling sesuai kriteria inklusi dan eksklusi. Penelitian dilakukan di RSUP Dr. Kariadi Semarang . Waktu penelitian dilakukan selama tiga bulan yaitu pada bulan April Juni 2018. Penelitian ini telah mendapat persetujuan Komisi Etik Penelitian Kesehatan (KEPK) Fakultas Kedokteran Universitas Diponegoro dan RSUP Dr. Kariadi Semarang yang tertuang dalam Ethical Clearance nomor: 71/EC/FK-RSDK/II/2018 tertanggal 19 Februari 2018. Subjek menyetujui serta menandatangani informed consent.

Subjek penelitian adalah penderita MDR-TB dan TB sensitif yang menjalani pengobatan dengan kriteria inklusi berusia $\geq 18$ tahun, mejalani rawat inap/jalan, tidak menderita Hepatitis, Human Immunodeficiency Virus - Acquired Immune Deficiency Syndrome (HIVAIDS), dan Diabetes Mellitus. Kriteria eksklusi pada penelitian ini yaitu subjek mengkonsumsi suplemen seng dan suplemen besi sehari sebelum pengambilan darah. Bahan dan alat yang digunakan yaitu timbangan digital, microtoice, rekam medik pasien, form recall konsumsi 24 jam, kuesioner pendukung, alat pelindung diri meliputi sarung tangan steril dan masker standar N95, disposable spuit $5 \mathrm{cc}$, plester, alkohol swab, vacutainer Ethylenediaminetetraacetic Acid (EDTA), vacutainer non-EDTA serta microtube.

Skrining dilakukan untuk menemukan subjek sesuai kriteria inklusi. Skrining berdasarkan rekam medik hasil pemeriksaan Tes Cepat Molekuler (TCM) dan kuesioner. Pengambilan data dilakukan setelah subjek sesuai kriteria inklusi dan menyetujui / menandatangani informed consent. Wawancara asupan makanan dilakukan untuk melihat asupan makanan terakhir dan pengukuran antropometri (berat badan dan tinggi badan) dilakukan oleh peneliti, sedangkan pengambilan darah dilakukan oleh perawat penaggungjawab poli MDR-TB/TB DOTS serta petugas laboratorium. Pengambilan darah diambil dari vena cubiti menggunakan spuit disposible $5 \mathrm{cc}$. Spesimen 
darah di sentrifus untuk memisahkan serum dan plasma kemudian dimasukan kedalam microtube.

Pemeriksaan kadar seng serum dilakukan dengan metode Quantitative Colorimetric Zinc Determination at 425nm, cut off point $70 \mu \mathrm{g} / \mathrm{dl}$. Pemeriksaan kadar MDA menggunakan metode Quantitatif Determination of Thioarbituric Acid Reaktive Substances (TBARS), dengan cut off point $2,59 \mathrm{nmol} / \mathrm{ml}$. Pemeriksaan serum seng dan MDA dilakukan di Laboratorium Terpadu Universitas Diponegoro Semarang. Uji beda kadar seng antara $M D R-T B$ dan TB sensitif menggunakan MannWhitney test, sedangkan uji beda kadar MDA antara $M D R-T B$ dan TB sensitif menggunakan Independent $t$ test.

\section{HASIL}

\section{Karakteristik Subjek Penelitian}

Penelitian dilakukan di Poli $M D R-T B$ dan Poli DOTS-TB RSUP Dr. Kariadi Semarang. Jumlah subjek 55 yang terdiri dari subjek $M D R-T B$ sebanyak 32 (17 laki-laki dan 15 perempuan) dan subjek TB sensitif sebanyak 23 (15 laki-laki dan 8 perempuan). Rerata usia subjek $M D R-T B$ adalah 39,41 $\pm 11,06$ tahun, sedangkan subjek TB sensitif 43,08 $\pm 16,94$. Rerata Indeks Massa Tubuh (IMT) subjek $M D R-T B$ adalah 17,20 $\pm 1,989$ $\mathrm{kg} / \mathrm{m}^{2}$ sedangkan subjek TB sensitif 19,28 $\pm 2,91 \mathrm{~kg} / \mathrm{m}^{2}$. Subjek dengan status gizi kurang (IMT $<18,5 \mathrm{~kg} / \mathrm{m}^{2}$ ) pada kelompok MDR-TB sebanyak 87,5\% $(\mathrm{n}=28)$ dan kelompok TB sensitif sebanyak 43,5\% $(n=10)$. Rerata asupan energi pada kelompok $M D R-T B$ lebih rendah $(2.372,6 \pm 240,8 \mathrm{kkal})$ dibandingkan kelompok TB sensitif $(2.454,0 \pm 232,7 \mathrm{kkal})$. Rerata asupan protein kelompok $M D R-T B$ lebih rendah $(80,30 \pm 19,6$ gr $)$ dibandingkan kelompok TB sensitif $(86,20 \pm 23,6$ gr). Rerata asupan lemak subjek $M D R-T B$ lebih rendah $(71,96 \pm 21,7$ gr) dibandingkan kelompok TB sensitif $(77,16 \pm 26,1$ gr). Rerata asupan seng kelompok $M D R$ $T B$ lebih tinggi $(67,43 \pm 20,7 \mathrm{mg})$ dibandingkan kelompok TB sensitif $(63,51 \pm 16,1 \mathrm{mg})$. Rerata usia, IMT dan asupan zat gizi disajikan pada Tabel 1.

Tabel 1. Rerata Usia, IMT dan Asupan Zat Gizi Subjek

\begin{tabular}{|c|c|c|c|}
\hline \multirow[b]{2}{*}{ Parameter } & \multicolumn{2}{|c|}{ Subjek } & \multirow[b]{2}{*}{$p$} \\
\hline & $\begin{array}{c}\text { MDR-TB }(\mathrm{n}=32) \\
(\text { Mean } \pm S D)\end{array}$ & $\begin{array}{c}\text { TB-sensitif }(\mathrm{n}=23) \\
(\text { Mean } \pm S D)\end{array}$ & \\
\hline Usia (tahun) & $39,41 \pm 11,06$ & $43,08 \pm 16,94$ & 0,546 \\
\hline IMT $\left(\mathrm{Kg} / \mathrm{m}^{2}\right)$ & $17,20 \pm 1,989$ & $19,28 \pm 2,91$ & 0,002 \\
\hline Asupan Energi (Kkal) & $2.372,6 \pm 240,8$ & $2.454,0 \pm 232,7$ & 0,204 \\
\hline Asupan Protein (gr) & $80,30 \pm 19,6$ & $86,20 \pm 23,6$ & 0,310 \\
\hline Asupan Lemak (gr) & $71,96 \pm 21,7$ & $77,16 \pm 26,1$ & 0,427 \\
\hline Asupan Seng (mg) & $67,43 \pm 20,7$ & $63,51 \pm 16,1$ & 0,278 \\
\hline
\end{tabular}

Tabel 2. Distribusi Frekuensi Subjek Penelitian

\begin{tabular}{|c|c|c|c|c|c|}
\hline \multirow{3}{*}{ Parameter } & \multicolumn{4}{|c|}{ Kelompok } & \multirow{3}{*}{$p$} \\
\hline & \multicolumn{2}{|c|}{$M D R-T B \quad(n=32)$} & \multicolumn{2}{|c|}{ TB-sensitif $(n=23)$} & \\
\hline & $\mathbf{n}$ & $\%$ & $\mathbf{n}$ & $\%$ & \\
\hline \multicolumn{6}{|l|}{ Jenis Kelamin } \\
\hline Laki-laki & 17 & 53,1 & 15 & 65,2 & \\
\hline Perempuan & 15 & 46,9 & 8 & 34,8 & \\
\hline \multicolumn{6}{|l|}{ Status Gizi } \\
\hline Kurang (IMT<18,5 kg/m²) & 28 & 87,5 & 10 & 43,5 & $0,005^{*}$ \\
\hline Normal $\left(\right.$ IMT $\left.\geq 18,5 \mathrm{~kg} / \mathrm{m}^{2}\right)$ & 4 & 12,5 & 13 & 56,5 & \\
\hline \multicolumn{6}{|l|}{ Tingkat asupan Energi } \\
\hline Kurang & 32 & 100 & 23 & 100 & \\
\hline Cukup & 0 & 0,0 & 0 & 0,0 & \\
\hline \multicolumn{6}{|l|}{ Tingkat asupan Protein } \\
\hline Kurang & 22 & 68,8 & 11 & 47,8 & 0,492 \\
\hline Cukup & 10 & 31,2 & 12 & 52,2 & \\
\hline \multicolumn{6}{|l|}{ Tingkat asupan Lemak } \\
\hline Kurang & 23 & 71,9 & 14 & 60,9 & 0,992 \\
\hline Cukup & 9 & 28,1 & 9 & 39,1 & \\
\hline \multicolumn{6}{|l|}{ Tingkat asupan seng } \\
\hline Kurang & 23 & 71,9 & 14 & 60,9 & 0,059 \\
\hline Cukup & 9 & 28,1 & 9 & 39,1 & \\
\hline
\end{tabular}

Keterangan : Klasifikasi Tingkat kecukupan gizi berdasarkan kebutuhan gizi individu 
Seluruh subjek baik pada $M D R-T B$ maupun TB sensitif memiliki tingkat kecukupan energi kurang dari kebutuhan gizi individu. Tingkat asupan protein kurang pada subjek $M D R-T B$ sebanyak $68,8 \% \quad(\mathrm{n}=22)$ dan subjek TB sensitif sebanyak 47,8\% (n=11). Tingkat asupan lemak kurang pada MDR-TB sebanyak 71,9\% $(\mathrm{n}=23)$ dan pada TB sensitif sebanyak 60,9\% $(\mathrm{n}=14)$. Tingkat asupan seng kurang pada MDR-TB sebanyak 28,1\% (n=9) dan pada TB sensitif sebanyak 34,7\% $(\mathrm{n}=8)$. Distribusi karakteristik subjek penelitian disajikan pada Tabel 2.

\section{Kadar Seng dan MDA}

Median kadar seng pada kelompok $M D R-T B$ adalah $74,85 \mu \mathrm{g} / \mathrm{dl}$ dengan rentang terendah $64 \mu \mathrm{g} / \mathrm{dl}$ dan tertinggi $97 \mu \mathrm{g} / \mathrm{dl}$, sedangkan pada kelompok TB sensitif adalah $73,03 \mu \mathrm{g} / \mathrm{dl}$ denga rentang terendah $63 \mu \mathrm{g} / \mathrm{dl}$ dan rentang tertinggi $97 \mu \mathrm{g} / \mathrm{dl}$. Rerata kadar MDA pada kelompok MDR-TB adalah 2,26 $\pm 1,05 \mathrm{nmol} / \mathrm{ml}$, sedangkan pada kelompok TB sensitif adalah 2,66 $\pm 0,99$ $\mathrm{nmol} / \mathrm{ml}$. Kadar seng dan kadar MDA subjek penelitian disajikan pada Tabel 3.

Tabel 3. Kadar Seng dan Kadar MDA Subjek Penelitian

\begin{tabular}{|c|c|c|c|c|c|}
\hline \multirow{3}{*}{ Parameter } & \multicolumn{4}{|c|}{ Kelompok } & \multirow{3}{*}{$p$} \\
\hline & \multicolumn{2}{|c|}{$M D R-T B \quad(\mathrm{n}=32)$} & \multicolumn{2}{|c|}{ TB-sensitif $(n=23)$} & \\
\hline & $\mathbf{n}$ & $\%$ & $\mathbf{n}$ & $\%$ & \\
\hline Kadar Seng $(\mu \mathrm{g} / \mathrm{dl})$ & \multicolumn{2}{|c|}{$74,85(64-97)$} & \multicolumn{2}{|c|}{$73,03(63-97)$} & \multirow{3}{*}{1,000} \\
\hline Defisiensi $(<70 \mu \mathrm{g} / \mathrm{dl})$ & 10 & 31,2 & 6 & 26,1 & \\
\hline Normal ( $\geq 70 \mu \mathrm{g} / \mathrm{dl})$ & 22 & 68,8 & 17 & 73,9 & \\
\hline Kadar MDA (nmol/ml ) & \multicolumn{2}{|c|}{$2,26 \pm 1,05$} & \multicolumn{2}{|c|}{$2,66 \pm 0,99$} & \multirow{3}{*}{0,147} \\
\hline Tinggi $(>2,59 \mathrm{nmol} / \mathrm{ml})$ & 9 & 28,1 & 11 & 47,8 & \\
\hline Normal $(\leq 2,59 \mathrm{nmol} / \mathrm{ml})$ & 23 & 71,9 & 12 & 52,2 & \\
\hline
\end{tabular}

Keterangan : $p<0,05=$ Bermakna

\section{PEMBAHASAN}

Hasil uji statistik menunjukkan bahwa tidak terdapat perbedaan kadar seng pada kelompok $M D R-T B$ dan kempok TB sensitif $(p=1,000)$. Hasil tersebut menunjukkan bahwa penyakit $M D R-T B$ dan TB tidak memberikan pengaruh yang berbeda terhadap status kadar seng. Nilai median kadar seng pada kelompok $M D R-T B$ lebih tinggi dibandingkan kelompok TB sensitif akan tetapi kadar seng pada kedua kelompok dalam kategori normal. Kadar seng serum dengan konsentrasi normal adalah $\geq 70 \mu \mathrm{g} / \mathrm{dl} .{ }^{28}$ Hasil Penelitian menunjukkan subjek pada kelompok $M D R-T B$ yang mengalami defisiensi sebanyak $31,2 \%$ sedangkan pada kelompok TB sensitif yang mengalami defisiensi seng sebanyak $26,1 \%$. Defisiensi seng disebabkan redistribusi seng ke hepar terikat pada metallothionein, dikarenakan peningkatan produksi sitokin pro-inflamasi, yaitu Tumor Nekrosis Factor-1 (TNF-I) dan interleukin-6 (IL-6). Akibat yang ditimbulkan adalah seng yang diambil oleh hepar meningkat dan menyebabkan konsentrasi seng dalam plasma berkurang. ${ }^{29}$ Konsentrasi seng serum yang rendah menunjukkan bahwa cadangan seng yang sedikit. Sedikitnya cadangan mencerminkan kehilangan seng di jaringan (terutama dari hati). ${ }^{30}$

Hasil penelitian ini tidak sejalan dengan penelitian Barman, et al., mengemukakan bahwa kadar serum seng ditemukan lebih rendah pada pasien $M D R-T B .{ }^{1}$ Kadar seng yang lebih tinggi pada penderita $M D R-T B$ dimungkinkan karena rerata asupan seng pada kelompok $M D R-T B$ lebih tinggi dibandingkam dengan kelompok TB sensitif. Konsentrasi seng serum dipengaruhi oleh beberapa faktor, salah satunya adalah waktu makan terahir dan jenis makanan yang dikonsumsi. ${ }^{31}$ Konsumsi seng yang tinggi, di dalam dinding sel saluran cerna sebagian diubah menjadi methallotionein sebagai simpanan, sehingga absorpsi berkurang. Dengan asupan seng yang tinggi, seng dapat diserap di antara sel. Simpanan ini akan dibuang bersama sel-sel dinding usus halus pada hari ke 2-5. Distribusi seng antara cairan ekstraseluler, jaringan dan organ dipengaruhi oleh keseimbangan hormon dan situasi stres. ${ }^{32}$ Kadar seng serum juga dipengaruhi oleh terapi pengobatan tuberkulosis. Penelitian yang dilakukan oleh Gupta et al., mengemukakan bahwa ada peningkatan kadar seng yang signifikan pada akhir terapi obat anti tuberkulosis. Meningkatnya kadar seng serum dimungkinkan karena terapi obat tuberkulosis menyebabkan penurunan jumlah kuman dan menyebabkan penurunan aktivitas antioksidan endogen yaitu supeoxide dismutase (SOD) dimana bahan penyusun utamanya adalah seng, dalam mendetoksifikasi reactive oxygen species (ROS). ${ }^{27,28}$ Peningkatan kadar seng pada akhir pengobatan kemungkinan merupakan penanda untuk memantau tingkat keparahan penyakit dan respon terhadap terapi. ${ }^{30}$

Tabel 3 juga menunjukkan bahwa tidak terdapat perbedaan yang signifikan kadar MDA pada kelompok $M D R-T B$ dan kelompok TB sensitif $(p=0,147)$. Hasil penelitian tesebut menunjukkan bahwa penyakit $M D R$ $T B$ dan TB sensitif tidak memberikan pengaruh yang berbeda terhadap status kadar MDA. Rerata kadar MDA pada kelompok $M D R-T B$ lebih rendah dibandingkan dengan kelompok TB sensitif. Rendahnya rerata kadar MDA pada kelompok MDR-TB kemungkinan 
dipengaruhi oleh kadar seng pada kelompok $M D R-T B$ yang tinggi. Seng menurunkan Reaktive Oxygen Sepecies (ROS) dengan beberapa mekanisme. Seng adalah penghambat oksidase Nikotinamida Adenin Dinukleotida Phospat (NADPH), diperlukan untuk pembentukan SOD, dan menginduksi metallothionein, yang sangat efektif dalam menurunkan hidroksi radikal $(\mathrm{OH})$. Radikal bebas memiliki reaktivitas tinggi dan dapat membentuk radikal baru. Reaksi radikal bebas akan terhenti apabila dapat diredam oleh antioksidan. ${ }^{33}$

Rerata kadar MDA pada kelompok TB sensitif lebih tinggi dibandingkan kelompok $M D R-T B$. Kadar MDA plasma yang tinggi sebagai penanda stres oksidatif didalam sel. Ketidakseimbangan antara ROS dan antioksidan akan menyebabkan terjadinya stres oksidatif. ${ }^{34}$ Hasil penelitian menunjukkan bahwa pada kelompok TB sensitif ditemukan kadar seng (penyusun utama SOD) ditemukan lebih rendah sehingga tidak terjadi keseimbangan antara ROS dan antioksidan menyebabkan terjadinya stres oksidatif. Malondialdehyde merupakan produk peroksidasi lipid khususnya asam lemak tak jenuh ganda yang diakibatkan aktivitas ROS yang tinggi. ${ }^{34}$

Mycobacterium tuberculosis adalah mikroorganisme fakultatif intraseluler yang mampu hidup dan berkembangbiak dalam makrofag dan tahan terhadap enzim-enzim lisosom sehingga sulit dibunuh. Sistem imun akan merespon kuman tersebut dengan fagositosis makrofag melalui respiratory burst, baik melalui proses oksidatif maupun non oksidatif yang membutuhkan oksigen dalam jumlah besar sehingga menyebabkan peningkatan aktivitas ROS yang diikuti dengan terbentuknya MDA..$^{35,36}$

\section{SIMPULAN}

Berdasarkan hasil penelitian maka dapat ditarik kesimpulan bahwa tidak terdapat perbedaan kadar seng dan kadar $M D A$ antara penderita $M D R-T B$ dan TB sensitif. Direkomendasikan penelitian lebih lanjut membandingkan kadar seng dan MDA pada MDR-TB dengan TB sensitif baru yang belum mendapatkan terapi OAT serta jumlah sampel yang lebih besar.

\section{UCAPAN TERIMAKASIH}

Ucapan terima kasih kepada Badan Pengembangan dan Pemberdayaan Sumber Daya Manusia (BPSDMK) Kementerian Kesehatan Republik Indonesia atas bantuan dana penelitian.

\section{DAFTAR PUSTAKA}

1. Barman N, Ghosh D, Rahman Q, Mn U, Ahmed S, Paul D, et al. Assessment of Risk Factors of Multidrug Resistant Tuberculosis with Emphasis on
Serum Zinc. Bangladesh Med J. 2014;43(1):3-8.

2. Lodha R, Mukherjee A, Singh V, Singh S, Friis H, Faurholt-jepsen D, et al. Effect of Micronutrient Supplementation on Treatment Outcomes in Children with Intrathoracic Tuberculosis: a Randomized Controlled Trial. Am J Clin Nutr. 2014;100(7):1287-97.

3. Widhyari SD. Peran dan Dampak Defisiensi Zinc (Zn). Wartazoa. 2012;22(3):141-8.

4. Rodriguez-Morales AJ, Bolivar-Mejía A, AlarcónOlave C, Calvo-Betancourt LS. Nutrition and Infection. Encycl Food Heal. 1st ed. 2016;(October 2015):98-103.

5. Pai M, Behr MA, Dowdy D, Dheda K, Divangahi M, Boehme CC, et al. Tuberculosis. Nat Rev Dis Prim. 2016;2:1-21.

6. World Health Organization. Global Tuberculosis Report. Genewa: WHO Press; 2015. 5-105 p.

7. World Health Organization. Global Tuberculosis Report. Genewa: WHO Press; 2016. 5-122 p.

8. Kementerian Kesehatan RI. Profil Kesehatan Indonesia. Jakarta; 2017. 160-167 p.

9. Dinas Kesehatan Provinsi Jawa Tengah. Profil Kesehatan Provinsi Jawa Tengah. Semarang; 2015. 18-22 p.

10. Kementerian Kesehatan RI. Pedoman Nasional Pengendalian Tuberkulosis. Jakarta; 2014. p. 1148.

11. Kementerian Kesehatan RI. Tuberkulosis, Temukan Obati Sampai Sembuh. Jakarta; 2016. 1-10 p.

12. Amalia L, Masyarakat DG, Manusia FE. Pengaruh Suplemen Antioksidan Terhadap Kadar Malondialdehid Plasma Mahasiswa IPB. J Gizi dan Pangan. 2014;9(1):35-42.

13. Spooner R, Yilmaz Ö. The Role of ReactiveOxygen-Species in Microbial Persistence and Inflammation. Int J Mol Sci. 2011;12:334-52.

14. Butler RE, Cihlarova V, Stewart GR. Effective Generation of Reactive Oxygen Species in the Mycobacterial Phagosome Requires K + Efflux From The Bacterium. Cell Microbiol. 2010;12(April):1186-93.

15. Shin D, Yang C, Lee J, Lee SJ, Choi H, Lee H, et al. Mycobacterium Tuberculosis Lipoproteininduced Association of TLR2 with Protein Kinase $\mathrm{C} \zeta$ in Lipid Rafts Contributes to Reactive Oxygen Species-Dependent Inflammatory Signalling in Macrophages. Cell Microbiol. 2009;10(9):1893905.

16. Wati YE, Muktiati NS, Astuti T. Studi Stres Oksidatif: Kadar Malondialdehyde dan Aktivitas Superoksida Dismutase Plasma pada Tuberkulosis Paru Lesi Minimal dan Lesi Luas. J Respir Indo. 2013;33(3):163-6.

17. Busch CJ, Binder CJ. Malondialdehyde epitopes as mediators of sterile inflammation. Biochim Biophys 
Acta - Mol Cell Biol Lipids. 2017;1862(4):398406.

18. Kulkarni R, Deshpande A, Saxena R, Saxena K. A Study of Serum Malondialdehyde and Cytokine in Tuberculosis Patients. J Clin Diagnostic Res. 2013;7(10):2140-2.

19. Altika S, Rahayu RSR. Analisis Total Status Antioksidan (TSA) Pasien Tuberkulosis (TB) Paru Kelompok Usia 30-60 Tahun di Wilayah Kerja Puskesmas Kecamatan Genuk Kota Semarang. Public Heal Perspect J. 2017;2(3):247-53.

20. Retnoningrum DS. Mekanisme Tingkat Molekul Resistensi terhadap Beberapa Obat pada Mycobacterium Tuberculosis. Acta Pharm Indones. 2004;XXIX(3):92-5.

21. Güney Y, Bilgihan A, Ciftçi TU, Çimen F, Coşkun O. Serum Malondialdehude Levels and Superoxide Dismutase Activities In Pulmonary Tuberculosis and Lung Cancers. Mesl Yüksekokulu Derg. 2004;6(2):33-8.

22. Prasad AS. Zinc: Role in Immunity, Oxidative Stress and Chronic Inflammation. Clin Nutr Metab. 2009;12:646-52.

23. Ramatina, Amalia L, Ekayanti I. Pengaruh Suplemen Anti Oksidan Terhadap Kadar Malondialdehid Plasma Mahasiswi IPB. J Gizi dan Pangan. 2014;9(1):35-42.

24. Valkoa M, Rhodesb CJ, Moncola J, Izakovica M, Mazura M. Free Radicals, Metals and Antioxidants in Oxidative Stress-Induced Cancer. Chem Biol Interact. 2006;160(1):1-40.

25. Prasad AS. Clinical, Immunological, AntiInflammatory and Antioxidant Roles of Zinc. Exp Gerontol. 2008;43:370-7.

26. Maywald M, Wessels I, Rink L. Zinc Signals and Immunity. Int J Mol Sci. 2017;18:1-34.

27. Bahi GA, Boyvin L, Méité S, M'Boh GM, Yeo K, N'Guessan KR, et al. Assessments of Serum Copper and Zinc Concentration, and $\mathrm{The} \mathrm{Cu} / \mathrm{Zn}$ Ratio Determination in Patients With Multidrug Resistant Pulmonary Tuberculosis ( MDR-TB ) in Côte d' Ivoire. BioMed Cent. 2017;17:1-6.

28. Gupta KB, Gupta R, Atreja A, Verma M, Vishvkarma S. Tuberculosis and Nutrition. Lung India. 2009;26(1):9-16.

29. Gropper SS, Smith JL. Advanced Nutrition and Human Metabolism. 6th ed. USA: Wadsworth, Cengage Learning; 2013. 500-510 p.

30. Gropper SS, Smith JL. Advance Nutrition and Human Metabolism. Sixth Edit. USA: Wadsworth, Cengage Learning; 2013. 500-510 p.

31. Berdanier CD, Zempleni J. Advanced Nutrition: Macronutriens, Micronutrients and Metabolism. 10th ed. New York: CRC Press; 2009. 476-482 p.

32. Almatsier S. Prinsip Dasar Ilmu Gizi. 8th ed. Jakarta; 2009. 259-63 p.

33. Prasad AS. Zinc: Role in Immunity, Oxidative Stress and Chronic Inflammation. Clin Nutr Metab. 2009;12:646-52.

34. Arkhaesi N. Kadar malondialdehyde (MDA) serum Sebagai Indikator Prognosis Keluaran Pada Sepsis. Universitas Diponegoro Semarang; 2008.

35. Nahid P, Dorman SE, Alipanah N, Barry PM, Brozek JL, Cattamanchi A, et al. Executive Summary: Official American Thoracic Society/Centers for Disease Control and Prevention/Infectious Diseases Society of America Clinical Practice Guidelines: Treatment of DrugSusceptible Tuberculosis. Clin Infect Dis. 2016;63(7):853-67.

36. Yuniastuti A, Yusuf I, Massi MN, Budu. Status Antioksidan Glutation pada Pasien Tuberkulosis Paru di Balai Kesehatan Paru (BKPM) Makassar. Biosaintifika. 2013;5(2). 